\title{
The Author as Arsonist: Henry James and the Paris Commune
}

\section{Scott McCracken}

Arriving in Paris midway through the 1890s, Lambert Strether, the protagonist of Henry James's 1903 novel, The Ambassadors, waits until his second morning before exploring the city he remembers from his first visit three decades earlier. After divesting himself of his irredeemably American companion, Waymarsh, he sets off on a walk that is also an evasion: a deferral of opening letters sent by his patron and possible future wife, Mrs. Newsome, which have followed him from the United States via London. Putting them off in a pretense to himself of looking for a place to read them, Strether passes an hour looking at the windows of shops in the Rue de la Paix before heading towards the Jardin des Tuileries, where he notes, not Paris as he had remembered it, but an absence: "The palace was gone." This lack triggers in Strether an uncanny "historic sense":

The palace was gone, Strether remembered the palace; and when he gazed into the irremediable void of its site the historic sense in him might have been freely at play-the play under which in Paris indeed it so often winces like a touched nerve. He filled out spaces with dim symbols of scenes...

The missing palace was the Palais des Tuileries, burnt down by the Communards in May 1871. It had completed the Cour du Carrousel, facing the Jardin des Tuileries, and enclosing the court at the center of which stood the Arc du Carrousel, built to celebrate Napoleon I's victory at Austerlitz. Strether remembers it because he was last in Paris in the mid-1860s, when he came on his honeymoon. He has changed, having lost both his wife and his son, and so has Paris. The 1860s had been the high

MODERNISM / modernity VOLUME TWENTY ONE, NUMBER ONE, PP 7I-87. @ 2014 THE JOHNS HOPKINS UNIVERSITY PRESS

\section{Scott McCracken} teaches at Keele University. He is the author of Masculinities, Modernist Fiction, and the Urban Public Sphere (Manchester University Press, 2007) and coauthor of Benjamin's Arcades:An Unguided Tour (Manchester University Press, 2006), with Peter Buse, Ken Hirschkop, and Bertrand Taithe. $\mathrm{He}$ is currently working on a book about literary and artistic responses to political defeat. 
MODERNISM / modernity

72 point of the Second Empire, when Paris had been transformed into a city of grand boulevards by Baron Haussmann. It was an age of public splendor, which culminated in the Paris Exhibition of 1867, but also of deep social inequalities, which persisted during the Prussian siege of Paris in the autumn and winter of 1870-71, and fed the discontent that led to the uprising that established the Paris Commune between 18 March and 28 May 1871.

While there is no comprehensive treatment of the Commune in James's work, the reference to the absence of the palace in The Ambassadors is one of many allusions, direct and indirect, to the event that are scattered throughout his writings. The paradoxical presence of the Commune as absence draws attention to what Pierre Nora calls the modern "rupture between history and memory":

from the idea of the a visible past to one of an invisible past; from a firmly rooted past to a past that we experience as a radical break in continuity; from a history that we believed lay in some sort of memory to a memory we think of as projected onto the discontinuity of history. ${ }^{2}$

In the history of France, which was as much for James as it was for Marx the model of national history, the origin of such ruptures was the Revolution, from which all subsequent insurrections, 1830, 1848, and 1871, took their cue. The play of absence and presence in the two clauses, "The palace was gone, Strether remembered the palace," initiates a process whereby Strether's personal sense of an unfulfilled life is positioned in relation to a larger temporality of defeat, for which the Commune is a resonant point of reference. James's relationship to the Commune has been little discussed until recently, ${ }^{3}$ but it is of interest for at least two reasons: first, for what it tells us about James's "historic sense"; second, because James deploys an aesthetic that engages with the rupture between memory and history that anticipates that of his modernist successors, Proust, Richardson, Joyce, and Woolf.

As this article will show, there was a curious homology between the material history of the Palais des Tuileries after 1871 and James's references to the Commune in his writings. Just as James's references to the event were scattered across his work, fragments of the ruined palace were scattered across Paris and beyond. This homology suggests one of the consequences of the modern rupture between memory and history: the memory of the event is, to use Proust's term, disaggregated (désagrégé) ${ }^{4}$ yet it persists as fragments, both material and textual, which still have the capacity to provoke remembrance. They signify not just the event, but also the possibilities the event might still promise, a promise akin to Walter Benjamin's "weak messianic power, a power on which the past has a claim." ${ }^{5}$

In the case of the Commune, the politics of remembrance were sharpened by the reaction that followed its defeat, when massacres, deportations, and censorship compelled an active forgetting. In that context, James's registration of the Commune as an absence figures the past as what he elsewhere calls "a mystery and a challenge." Its representation invokes a paradox: in order to register what has gone, the author must first 
re-enact its destruction - "the palace was gone." To provoke remembrance, "Strether remembered the palace," James has to collaborate in the original act of arson, but what remains is not the thing itself, but its vestiges. For the modernist artist, the remnants of the past offer three different aesthetic responses: restoration, reconstruction, or final, complete obliteration of the event. Two of these possibilities can only be imaginary. True restoration assumes an imaginary origin, which can never be rediscovered. Total elimination is possible, but unlikely, as traces around which the work of memorialization can be done will always persist. Reconstruction, on the other hand, is always more than material restoration. The repositioning of fragments, whether actual vestiges or representations of the "original," into a new composition involves a new aesthetic, which engages with the future as well as the past. James pioneered a narrative method that was aware of all these possibilities. Not only does his fiction consider all three, but it offers a way of reading the historical in modernist texts.

\section{The Commune, Revolution, and History}

A revolution within a revolution, the Paris Commune lasted only a few weeks. The more enduring Third Republic had been declared first, on 4 September 1870, after the defeat of the Second Empire and the capture of Napoleon III by the Prussians at the Battle of Sedan. The Prussians then besieged Paris, which capitulated after 135 days. The Commune rose out of a sense that France has been betrayed, ignited by an attempt to disarm the working-class districts of Paris of the weapons they had paid for through popular subscription. The Prussians remained invested to the east of the city throughout the Commune, but it was the government of the Third Republic led by Adolphe Thiers, exiled in Versailles after 18 March, that organized a renewed siege and eventually the reoccupation of Paris in la Semaine Sanglante, the Bloody Week, of 21-28 May, when between 20 and 30,000 men, women, and children were shot and buried in mass graves.

Since 1871 the perceived significance of the Commune has waxed and waned with the political temperature of the times. Interest has revived during recent protests and uprisings, but in periods of political quiescence it has faded from view or has been dismissed as a form of collective madness. ${ }^{7}$ The Commune's bloody suppression resulted in a period of enforced silence in France in the 1870s, when strict censorship forbade its mention in public or in print. The legacy of this decade persists in the sense that even now the Commune is written about as a form of reverse discourse: discussion is often prefaced with a statement about how it has been excised from the history of modern France. The paradox of the Commune is that it is represented through a discourse of its non-representation. In this respect, James's registration of the event through an absence is typical, but the sense of having missed the chance to "live" is also part of the temporality of the narrative of The Ambassadors, which is characterised by what Kevin Ohi calls a form of "belatedness." As Ohi notes, this sense of belatedness is written into the linguistic structure of the novel, ${ }^{9}$ a belatedness he reads in terms of the queer understanding that follows coming out of the closet. ${ }^{10}$ This article will focus on 
MODERNISM / modernity

74 another dimension of belatedness, the recognition by James of the past as a problem that raises a particular set of specifically modernist aesthetic questions.

There is a strong association between history and revolution in James's work. In his memoir of 1913, A Small Boy and Others, there is retrospective evidence that it was an earlier revolution in France that first triggered the young James's historic sense. News of the escape of Louis Philippe, the "bourgeois" king deposed in 1848, brought by his uncles to the family's New York apartment, made a lasting impression: "These last words, flight of the king, linger on my ear at this hour even as they fell there ... I had heard of kings presumably, and also of fleeing: but that kings had sometimes to flee was a new and striking image, to which the apparent consternation of my elders added force."11 Typically, James renders the authenticity of the experience uncertain- "So much, in any case, for what I may claim—perhaps too idly—on behalf of my backward reach"; ${ }^{12}$ but the choice of memory, restored or reconstructed, is significant as is the accompanying, perhaps equally reconstructed, recall of the Place de la Vendôme, (with its column erected by Napoleon I, toppled during the Commune and then reerected in 1874) from his first visit to Paris as an infant of two. ${ }^{13}$ Paris, revolutionary politics, and a sense of history were what the late James chose to remember about his introduction to France.

The James family spent more time in France in the mid-1850s, so that James's first experiences of the country were of the Second Empire. The adult James visited France again in in 1869 and early 1870 before returning to the United States on 30 April, just before the outbreak of war. It is clear from his letters from this time and later memoirs that he followed French politics, the Franco-Prussian war, and the subsequent revolutions closely. ${ }^{14}$ His initial response to the Second Empire's defeat was disillusion with France and French culture, which the James family had always held in high esteem. On 20 September 1867, he had written to Thomas Sergeant Perry that Paris was "une des merveilles de l'univers," "city of my dreams!"15 After the Battle of Sedan, however, he felt that the French, and by implication the Second Empire, had got what it deserved. On 26 September 1870, he wrote to Grace Norton:

You have been feeling, I suppose, very much as we (we, I mean of this immediate family) —are feeling, that is, strongly with the Germans. The war up to this time, has to my perception effected such a prodigious unmasking of French depravity \& folly that is has been in a measure blessed \& sanctified, in spite of its horrors, by this i[ll]uminating \& disillusioning force. All the French utterances I read, seem to me, almost unexceptionally, those of barbarians \& madmen. ${ }^{16}$

He had little sympathy at first with the Third Republic, writing in the same letter: "The fortune of the French Republic, it seems to me, has not as yet been so brilliant as to offer a very enticing example to latent Republicanism elsewhere. I rather doubt its duration in France. ${ }^{\prime 17}$ But on 18 April 1871, during the Commune itself, he wrote again to Grace Norton: 
There is a certain not altogether unnatural feeling abroad, I think, that we are after all trying to help the French against their will) — that they prefer to be foolish \& miserable \& that they are welcome to it. I confess that the history of the French people for the past many weeks is something from which I as one qui les a bien aimé am fain to avert my face. I haven't the heart to talk of them ... But its [sic] useless talking or guessing or sorrowing about France. She's a grim object enough. She holds her fate in her own hands \& no one can help her or advise her but herself)—she who feels poor creature! ) - her bosom torn and shaken with all the raging elements of the problem. All one can say is poor poor France! \& yet there is a kind of resignation in ones [sic] pity: the healthy sentiment of satisfaction that we must feel in seeing folly \& vanity \& iniquity attended by a smothering, stifling, trampling succession of mortifications, defeats \& penances. What Germany has done, in a broad way, has simply been to give France over to herself: that self apparently is so weak so vicious, so unveracious (as Carlyle would say) that she receives the great gift \& charge into a yawning bloody gulf of disorder - a vainer vanity than ever! The Germans have done more than they deem) _ haven't they? ) — and builded better than they knew. They have enforced certain homely truths as never in all history they can have been enforced, \& the silent economy of one's moral life draws vigor from their example. Live for shows \& names and glory of things \& not for their bitter, nutritive, essential forces and values) - and you'll have the trampling Germans of the universe let loose upon you ... In my secret heart I do nothing but weep for the French; but when I come to talk aloud, even to myself, I find that propriety heals my tears. They have suffered unutterably, they have sinned unutterably. As for the Germans, you may be sure I don't care a straw for them!18

The Second Empire had got what it deserved, but this condemnation does not seem to have extended to Paris, which James visited only a year and one month after la Semaine Sanglante. ${ }^{19}$ In June 1872 , he was more upbeat, to his parents at least, to whom he wrote on the 28th: "I had expected to receive all sorts of painful impressions \& to feel the shadow of Bismarck \& the Commune lying on everything. But to the casual eye there are no shadows anywhere, \& Paris is still the perfection of brightness \& neatness \& form \& taste. ${ }^{\prime 20}$ The tone of the letter is perhaps misleading. James might have wanted to allay his parents' fears, particularly as he had brought his younger, invalid, sister, Alice. A line in a later article, "The Parisian Stage" (9 January 1873), for Nation, makes it clear that he did visit the less than bright and neat, burnt-out buildings that littered the city, which had become what Michelle Coghlan describes as an "instant tourist destination." ${ }^{21}$

I shall never forget a certain evening in the early summer when, after a busy, dusty, weary day in the streets, staring at the charred ruins and finding in all things a vague aftertaste of gunpowder I repaired to the Théatre Français... ${ }^{22}$

In subsequent letters from the trip, which extended beyond France, James veered between taking comfort in the "old Paris"23 that remains and feeling discomfort in the memory of the "inequities and horrors" ${ }^{24}$ of the recent past. He could no longer feel secure in the city: "I shall never live in Paris but with my trunks packed"; ${ }^{25}$ and to his brother William, he wrote: "The want of comprehension of the real moral situation of France leaves one unsatisfied, too. Beneath all this neatness \& coquetry, you seem to smell the Commune suppressed, but seething." ${ }^{26}$ 
MODERNISM / modernity

76 If these letters show the strong emotions the overthrow of the Second Empire and the subsequent social upheaval evoked, James' politics at this time were characterised by a moderate Republicanism informed by the American model. He was anti-monarchist and found the enforced dominance of conservative views in Paris in the 1870s unappealing. In the same letter to William he reported that he read the anti-Communard Le Figaro "religiously," but it left "a bad taste in my mouth." ${ }^{\text {" } 7}$ In early November, he described to his father an unpleasant evening he had experienced in comic terms:

It consisted of a political fight between four conservatives (one the Marquis de Grammont, a deputy \& legitimist,) and a 'solitary republican', a Wallachian by birth. All the classic qualities of the French nature were successively unfolded before us, and the manner of it beat the best comedy. ${ }^{28}$

The absurdity of these characters probably lies behind all James's later fictional representations of support for French autocracy. It informed the representation of the aristocratic de Bellegardes in The American (1877) and it seems to have influenced his attitude towards the Third Republic. Despite his initial doubts, James started to develop a sympathy for the wily Thiers, architect of the Commune's defeat, supporting him in his battles with the Monarchist majority (but divided between antagonistic Bonapartist, Bourbon and Orleanist supporters) in the National Assembly. ${ }^{29}$ How far James sympathised with those ordinary Parisians who had been the chief victims of the Bloody Week is unclear, but by 16 December 1872, he had developed a kind of non-specific sympathy for Paris as an entity:

As my departure grows nigh, I find that I have grown very fond of this massive \& glittering capital. It's a great place, after all \& now that I have grown tolerably familiar with it, I have a kindly feeling towards it, \& during the next Communist brûlerie \& tuerie, which is pretty sure to come sooner or later, I'm sure I shall suffer agonies of sympathy. ${ }^{30}$

The sympathy here seems at first to be with the material city of Paris, but the synedoche is uncertain in its reach. The position of "Communist brûlerie \& tuerie" (burning and killing) in the sentence makes it unclear whether his consistent appreciation for the city, as opposed to France, might also have included a degree of sympathy for the Communards themselves. At the very least, the Paris Commune instigated a problem of representation.

\section{Fiction and Remembrance}

If references to the Commune in James's fiction appear in a dispersed form, as a kind of literary debris or ruins, the pattern for this treatment of revolutionary France is established early in his career. In a short story of 1869, "Gabrielle de Bergerac," which begins just before the first revolution, the conflict between old and new is framed as a retrospective narrative that starts with a vestige of the past: a portrait of the young woman. In the story, a pair of star-crossed lovers, the daughter of an aristocratic family 
and her nephew's tutor, a veteran of the American War of Independence, elope and go to Paris where they participate in the events of 1789 . They are subsequently guillotined as Girondists: their political choice representing James's own middle republican course between monarchism and Jacobin terror. The lovers' participation in the French Revolution seems to be a mere footnote, yet the persistence of the portrait as a vestige of the past from which the young woman's narrative might be reconstructed suggests the possibility of redemption, both for the promise of her life and for the two inaugural insurrections of the age of revolution, the French and the American.

The American (1876-7), which is set in the 1860s (but was written 1876-77 and revised in the New York edition in 1907), returns to the conflict between old and new. The eponymous hero, Christopher Newman, attempts to marry into a legitimist family. ${ }^{31}$ Newman is, as his name suggests, largely ignorant of French politics. In the 1876-7 edition, he regards the belief in divine right held by his fiancés elder brother, M. de Bellegarde, as a form of eccentricity, comparing it to "a taste for certain oddities of diet." ${ }^{2}$ In the New York Edition of 1907, however, the passage is re-written as a longer paragraph, which ends: $:^{33}$

He relapsed, to his own sense into silence very much as he would have laid down, on consulting it by mistake, some flat-looking back-number or some superseded time-table. It would do for the 'collection' craze, but it wouldn't do for use. ${ }^{34}$

The analogy is ambiguous. Read in one way, monarchism is understood by Newman to be irrelevant, useless. However, the idea of collecting calls to mind a different response to the past, that of Walter Benjamin's collector, who:

makes his concern the transfiguration of things. To him falls the Sisyphean task of divesting things of their commodity character by taking possession of them. But he bestows upon them only a connoisseur value, rather than use value. The collector dreams his way not only into a distant or bygone world but also into a better one- one which, to be sure, human beings are no better provided with what they need than in the everyday world, but in which things are freed from the drudgery of being useful. ${ }^{35}$

If, in the late, revisionist James, the idea that the past is collectable is countenanced, it is not clear whether those, like Newman, who take that view are culpably ignorant, as John Carlos Rowe suggests, or perceptive. ${ }^{36}$ The problem of what to do with the vestiges of the past (which would include the Bellegardes and the monarchist tendency in French politics), far from being irrelevant, is dangerously current, presenting a problem of recomposition, which will become familiar in later modernist fiction. Before looking at the references to the Commune in James's fiction, another analogy is helpful. The material history of the missing palace in The Ambassadors offers a parallel history to that of the event of the Commune in James's writings. It was destroyed, but its ruins were scattered far and wide, becoming curiously collectable as part of new compositions, in homes, public gardens, and even as new buildings, each of which suggested new patterns of meaning. 
MODER N I M / modernity

\section{The Afterlife of a Palace}

Historically the official royal residence in the center of Paris, the Palais des Tuileries, had also had an important role in republican history since 1789. In 1792, it was invaded twice by the Paris mob, who visited again in 1830 and 1848. After Napoleon III's coup d'état in December 1851, he installed himself in the Tuileries, a direct provocation not only to the defeated republicans but to the idea of republicanism itself. With the fall of the Second Empire in 1870, the Empress exited rapidly and in secret after her husband's capture at Sedan. For almost a century the palace had been symbol of a wider political struggle and it would remain so for the next twelve years.

During the first siege of Paris, it housed a military hospital and weapons factory. The new administration of Adolph Thiers left it empty and when the Paris Commune was declared on 18 March 1871, the still opulent palace was taken over by the people. Visits to its historic apartments cost 50 centimes and patriotic concerts were organised in the Salon des Maréchaux. ${ }^{37}$ The last of these, in aid of the widows and orphans of the Commune, was held on Sunday 21 May and attended by thousands. It ended with a speech by an officer, who declared defiantly: "Citoyens, $M$. Thiers avait promis d'entrer hier dans Paris; $M$. Thiers n'est pas entré; il n'entrera pas. Je vous convie pour dimanche prochain, ici à la même place, à notre second concert au profit des veuves et des orphelins" [Citizens, M. Thiers promised to enter Paris yesterday; M. Thiers has not entered; he will not enter. I invite you next Sunday, here in the same place to our second concert in aid of the widows and orphans].$^{38} \mathrm{~A}$ few hours after these words were uttered, the Versaillese troops entered through an unguarded gate at Saint-Cloud.

The government troops advanced quickly. By Monday evening, there were shells exploding in the Jardin des Tuileries. By the Tuesday afternoon, the local commander, General Jules Bergeret, had received orders to burn down the palace. ${ }^{39}$ The politics of arson in the defence of the Commune are still controversial. In a few cases, including the Tuileries, the Communards defended its use as a means of impeding the progress of the Versaillese; but more often they claimed that the extensive damage to Paris had been caused by the invading army, not the Communard fighters, nor the notorious (but largely mythical) female arsonists, les pétroleuses. If the Palais des Tuileries was one of the few buildings the Communards admitted to burning deliberately, ${ }^{40}$ the benefits of its destruction as a form of defense were debatable. It was its symbolic value that counted. According to the historian Babelon, "le palais disparaît précisément parce qu’il est reconnu comme un lieu de la mémoire" [the palace disappeared precisely because it is recognised as a place of memory]. ${ }^{41}$

Despite the national guard's reputation for disorder and poor discipline, they made a thorough job of it. Oil, tar and gunpowder were spread through the ornate rooms. At ten in the evening, the fire was lit using long poles thrust through the open windows. General Bergeret watched the flames rise as he ate his dinner on the other side of the court. Around midnight the central dome crumpled and at half past the great clock sounded for the last time. The blaze was intense. No one could get close for several days. ${ }^{42}$ By the end, the palace lay in ruins, a too visible eyesore in the centre of the city, an enduring reminder of the Commune's violent end. Most of the buildings 
damaged and destroyed during the Semaine Sanglante, such as the Hôtel de Ville, the headquarters of the Commune, were quickly restored, but as a potent symbol of monarchy and Empire, the ruins of the Palais des Tuileries remained controversial. The new administration could not agree on what was to be done and for twelve years they lingered as an uncomfortable tourist attraction, mentioned in Baedeker ${ }^{43}$ and visited as we have seen by James himself, a reminder that the Third Republic had been born amidst scenes of violence and destruction-in other words, an unwelcome memorial to the Commune and its suppression.

Three solutions were considered: restoration, the palace would be restored from its ruins; reconstruction, the old structure would be removed and a new monument reconstructed; and obliteration, although the view that the palace should be demolished was at first only held by a minority. ${ }^{44}$ From the outset, restoration of the central palace proved impractical. It was highly unstable and only the North and South sides of the Cour du Carrousel could be successfully repaired. However, further progress was bogged down in the parliamentary struggles between the monarchist factions and the republicans. By 1875, the republicans were in the ascendancy and the project lost support. Between 1876 and 1881, four commissions and four successive ministers pondered what to do, with restoration still the favoured option, despite the technical difficulties. Projected uses of the palace varied from an exhibition space for contemporary art to a chamber for the Senate or government offices. The complexity of the arguments was paralysing. As the decade proceeded, the idea of total destruction reemerged. The site had become an insalubrious and shameful memorial in the center of Paris. In 1881, the republican administration of Gambetta offered an amnesty to imprisoned, deported, and exiled Communards. The ruins were now an embarrassing reminder of conflict at a time of attempted reconciliation. Legislation authorizing the demolition was ratified in June 1882 and was carried out in 1883. ${ }^{45}$

But that was not the end of the palace. Its vestiges continued to provide a supply of objets trouvés. Even now, there is a vast cage on one side of the Jardin des Tuileries containing large chunks of stone and broken pillars. These were recomposed in a variety of montages across a wide range of private and public settings. Fragments were sold as domestic collectables, as souvenir paperweights, for example. ${ }^{46}$ Two of the palaces' arches stand without explanation near the grotto in the Jardin du Trocadéro. On one there is a small municipal sign telling the curious where the nearest fire hydrant is "en cas d'incendie," an ironic clue to its origins. The pediment from the central dome (with the clock that sounded for the last time at half past midnight on 24 May) crowned the entrance to the firm that carried out the demolition before being moved to the Place de George-Cains where it now resides, embedded in a wall with other remnants of the palace. Many of the other vestiges were also used decoratively, for example, as the arch at the Ecole des ponts et chaussées, or positioned picturesquely in the gardens of large houses, evoking what the historian of the palace, Guillaume Fonkenell, calls "l'imaginaire du jardin à l'anglaise peuplé de ruines." ${ }^{77}$ There is a fragment in Berlin by the Schwanensee lake, but perhaps the most extraordinary creation was the Château de Punta in Corsica, a whole new stately home which was built from remnants of the 
MODERNISM / modernity

80 palace for the Pozzo di Borgo family and which is now itself in need of restoration. ${ }^{48}$

A proper consideration of the positioning and arrangement of these fragments should be done in the context of the nineteenth-century vogue for ruins, ancient and contemporary, a fashion that began with Constantin Volney's The Ruins or Meditations of the Revolutions of Empires, published in 1791. Volney's text inaugurated a postrevolutionary enthusiasm for the remnants of past civilizations, ancient and modern, an enthusiasm that intensified in the aftermath of the Commune. ${ }^{49}$ The afterlife of the palace, a symbol of monarchy whose ruins became a symbol of its overthrow, corresponds to a recognizably modernist set of cultural responses to the reaction that follows a revolution's defeat. The erasure of the event is never total. Traces both material and textual are always left over, and the collection and rearrangement of these vestiges offers the same three possibilities as for the palace: restoration, the making of a lost connection with the past; reconstruction, a re-engagment with the past and an anticipation of the future; obliteration, the cutting off from the past to make a new future.

\section{The Ruins of the Past}

Although James does not mention the debates about the palace directly, ruins intrigued him. In a letter to William James in December 1872, he compared "some 'views' of the burnt district" pictured in the Illustrated London News to the ruins of the ancient city of Palmyra. ${ }^{50}$ In his collection of travel writings, Transatlantic Sketches, the reference to the charred remains left by la Semaine Sanglante is one amongst over a dozen references to vestiges of the past, from geological time to the present: rocks that look like ruins in Devon, Roman ruins, English ruins, European ruins. He was particularly interested in the work of Mr. Temple Leader, an Englishman who had "restored" a castle, Vincigliata, outside Florence. As he made clear, the idea that Vincigliata is a "restoration" is fiction. It is "a massive facsimile," "the apartments are ... as good a 'reconstruction' as a tale of Walter Scott.” They represented not history but a "disinterested work of art ... a triumph of aesthetic culture"; ${ }^{51}$ but while not in themselves historical, Leader's aesthetic still posed historical questions: "These crepuscular chambers ... are a mystery and a challenge; they seem a mere propounding of a riddle. ${ }^{" 52}$ The legacy of the Commune represented a comparable riddle. References to the Tuileries in James's fiction after 1871 need to be understood in terms of his understanding of the vestiges of the past as both an aesthetic and an historical problem for the modern artist.

In The Portrait of a Lady (1881), for example, the Tuileries appear in the context of reactionary nostalgia for the Second Empire. Mr Luce, a "high—or rather a deep— conservative," remarks to his fellow American, Mrs. Touchable:

"Why, madam, sitting in the Champs Élysées, opposite to the Palace of Industry, I've seen the court-carriages from the Tuileries pass up and down as many as seven times a day. I remember one occasion when they went as high as nine. What do you see now? It's no use talking, the style's all gone. Napoleon knew what the French people want, and there'll be a dark cloud over Paris, our Paris, till they get the Empire back again." 53 
Luce's "the style's all gone" anticipates Strether's "the palace was gone," at a time when it was still a visible ruin. The downfall of the Second Empire is not the main focus of the novel, but an idea of European decadence is. In that context, the reference acts to invoke a history for which the future is still unknown.

In The Princess Casamassima (1886), the reference to the Tuileries is even more oblique. It comes at the end of a walk taken by the novel's hero, Hyacinth Robinson, which foreshadows and parallels Strether's stroll in The Ambassadors. Like Strether walk, it begins close to the Opéra, at the Café Tortoni in the Rue des Italiens, and then runs parallel to the Rue de la Paix, ending at the other end of the Jardin des Tuileries in the frequently renamed Place de la Concorde, a square with even stronger associations of French revolutionary history: "The place itself-the Place Louis Quinze, the Place de la Révolution — had given him a sensible emotion, from the day of his arrival; he had recognised so quickly its tremendously historic character." ${ }^{54}$ Louis XVI had been executed there, only a short distance from the Palais des Tuileries, where he had, until its invasion in 1792 , been kept under arrest. The reference in the text to the "little wood of the Tuileries on one side" represents only the slightest of references to the king's journey from palace to execution, but it comes at a crucial moment in the narrative, when Hyacinth is deciding whether to go through with a political murder, which he and his co-conspirators hope will spark a new revolution. He experiences the dilemma as a choice between an aesthetic appreciation of the past glories of European civilization and a consciousness of the destruction the political change he wants will bring about, exactly the same dilemma posed by the ruins of the palace.

The Princess Casamassima is unusual in the James canon in that it contains direct rather than allusive references to the Commune..$^{55}$ The novel's content is overtly political, and two Communard exiles, a couple, Monsieur and Madame Poupin, are an early influence on the young Hyacinth. Hyacinth himself is the illegitimate son of an English Lord and a French republican: his grandfather had fallen, "in the blood-stained streets of Paris, on a barricade with a gun in his hand." ${ }^{\circ 56}$ His mother dies in prison after a life sentence for the murder of Hyacinth's father: a crime Hyacinth interprets as a revolutionary act to avenge her abandonment by her lover. Despite the novel's inclination towards Zolaesque naturalism, Hyacinth's heredity plays out in a manner that is more symbolic than biological. Caught between two clashing tendencies, French revolutionary violence and English class privilege, he grows ever more ambivalent about political action. In the end, he cannot bring himself to go through with the political murder he has vowed to commit. Fearing it would succeed in its revolutionary aim, instead he takes his own life.

Paris has a profound effect on his decision. In a visit there, Hyacinth experiences its topography as both saturated with political history and as an aesthetic experience, feeling on the one hand that he is being led through the streets by the ghost of his republican grandfather and on the other the fragility of the city's beauty. ${ }^{57}$ Princess Casamassima is, like The Ambassadors, primarily a narrative of personal defeat, but one that displays a now familiar modernist aesthetic. The narrative charts the attempts of an insurgent movement to gather together and to recompose the vestiges of earlier 
MODERNISM / modernity

82 defeats, but their efforts remain dispersed and, like Hyacinth's motivation to act, ultimately they fail. Rather than point to a new dawn, the narrative acts more as a form of remembrance, operating to reconstitute the past, registering events which, like the Palais des Tuileries, might otherwise be lost to memory.

Commemoration, the act of registering an absence-and in James's imagination, it would appear, the Tuileries and revolution are one-is on the one hand, a repetition of that destruction, the author as arsonist, but on the other an act of reconstruction of that which has been destroyed. Like later, comparable acts of modernist vandalism, Duchamp's moustache on the Mona Lisa or Delauney's shattered image of the Eiffel Tower, its performance is the prerequisite for new compositions made out of the fragments of that which has been destroyed. The act of recomposition as a response to what has been lost raises again the hopes of the past, but also a more conservative impulse: the possibility of restoration, which in this context is a word that is usefully ambivalent, signifying the replenishing of the weak (the defeated), the restoration of a building from a ruined state, but also, of course, Restoration with a capital $\mathrm{R}$, the return of the King, of the ancien régime.

\section{Re-reading The Ambassadors}

Thus the reference to the palace in The Ambassadors, to which I at last return, has a genealogy. Even the empty space Strether sees cannot be read as innocent of history and politics. In 1889, the architect Edmond Guillaume had renewed the gardens on the empty site of the old palace, making them into a kind of antechamber of the Jardin des Tuileries between the two arms of the now incomplete Cour du Carrousel. What had been a ceremonial court had become an open and democratic, public space. All vestiges of the palace had been eliminated, but for those such as Strether who remembered, it created the paradox of a visible "void," which provoked a problem in memory, a "raw nerve," the absence of a memorial to either the palace or the thousands of corpses on which the Third Republic was founded.

In the light of that history, the passage which precedes the shock of the moment when Strether's "historic sense" is brought to consciousness can be read as a complex representation of the workings of memory, in which the act of destruction has to be re-presented in order not to restore, but to reconstruct it through an act of remembrance. In order to facilitate that reconstruction, Strether's passage through Paris, and the reader's experience of it, is not represented as it happens, but through reflection. He walks through the gardens and across the river before stopping by the book stalls on the Left Bank to reflect on his pause in the Tuileries:

he came down the Rue de la Paix in the sun and, passing across the Tuileries and the river, indulged more than once-as if on finding himself determined—in a sudden pause before the book stalls of the opposite quay. In the garden of the Tuileries, he had lingered, on two or three spots, to look; it was as if the wonderful Paris spring had stayed him as he roamed. The prompt Paris morning struck its cheerful notes - in a soft breeze and a sprinkled smell, in the light flit, over the garden-floor, of bareheaded girls with 
the buckled strap of oblong boxes, in the type of ancient thrifty persons basking betimes where terrace walls were warm, in the blue-frocked brass-labelled officialism of humble rakers and scrapers, in the deep references of a straight-pacing priest or the sharp ones of a white-gaitered red-legged soldier. He watched the little brisk figures, figures whose movement was as the tick of the great Paris clock, take their smooth diagonal from point to point; the air had the taste as of something mixed with art, something that represented nature as a white-capped master-chef. The palace was gone... ${ }^{58}$

Two aspects of the passage license a strong reading that relates Strether's personal sense of loss to a more political "historic sense." First, the shift to the pluperfect "he had lingered" (my emphasis), enabled by his reflection on the immediate past, sets up a double memory of his first and second visits to Paris, before and after the Commune. This double memory is reinforced by Strether's sudden consciousness of the "wonderful Paris spring," the first reference to the season in the novel. Strether's memories of his earlier visit to Paris are so strong that it is difficult not to feel that the spring that "had stayed him as he roamed" reminds him not just of his sense of a wasted life, but also the hopes of his first visit on his honeymoon. Second, the final clause, before he returns to himself and his duty to Mrs. Newsome, projects a moment of fantasy beyond his immediate time and place: "He filled out spaces with dim symbols of scenes." Strether seeks recourse to fantasy in the face of the absence of the palace suggests a stronger, more political reading of the passage, in which another wonderful March is invoked, the declaration of the Commune on 18 March 1871. In such a reading, the characters who populate the gardens might be read, not just in terms of Strether's sharp sense of a life that has passed him by, but as "dim symbols" of a free Paris, with its bare-headed girls, the elderly at leisure, its municipal officials, and the contrasts of the priest and the citizen soldier representing both religious and secular freedoms. In this fugue, Paris as a "great...clock" works as an image of time figured as space, where the garden's diagonal paths represent the clock's hands; and for those who know the history of the palace, the empty space also sets up an uncanny reminder of lost time: the clock once set in the fronton of the Palais des Tuileries, which last sounded at halfpast midnight on Wednesday 24 March 1871, just before the dome crumpled inwards.

The passage is a striking example of how one of the consequences of political defeat, the process of dispersal-a dispersal of people, texts, and objects—is absorbed and responded to by modernist aesthetics. Even where the site of the defeat itself is replaced by a void, an empty space, the continued existence of disaggregated fragments and vestiges offer the imaginative possibilities of destruction, restoration, or recomposition as collage or montage. The other allusions and references to the Commune in James's work operate in a comparable way. Fragments of the past are encountered in the contexts of acts of remembrance, usually associated with particular places. The act of remembrance registers both loss (elimination) and the yearning for restoration, but the textual form is itself an act of collection and re-configuration, which reconstructs the past in the present, performing the role Walter Benjamin demanded of historical criticism: "It is not a question of representing works of literature in the context of their time, but to bring to representation, in the time when they were produced, the time which recognises them-that is, our time." 60 
MODERNISM / modernity

\section{Henry James and the Politics of Defeat}

The Ambassadors is about far more than Strether's personal sense of failure, or even the satisfaction of being able to articulate what you have missed. ${ }^{61}$ Strether's defeat is interwoven with the history of Paris, and for modernism, Paris was always more than a cultural and artistic centre; it was a political crucible in which the forces of old and new were in conflict. James's aesthetic creates a paradigm that is followed by later writers of modernist prose: an insistence on not letting go of the past, even if that means opening up old wounds. Thus, even at the end of The Ambassadors, in the culminating interview with Madame Vionnet, revolution, this time that of 1792, rises again. Strether sees in her dress echoes of the executed Girondiste, Madame Roland. ${ }^{62}$ The "plash of the fountain" ${ }^{\prime 3}$ echoes "the plash of the great fountains" ${ }^{64}$ Hyacinth hears in the former place de la Révolution. Strether's "odd starts of historic sense" return and with them "the smell of revolution, the smell of public temper-or perhaps simply the smell of blood.." The personal is saturated with past time and James's geographical and historical references constantly evoke that past in a way that leaves the future uncertain. History in this respect is never only of antiquarian interest. Disputes over vestiges and fragments draw up new lines of conflict, so that old battles can be remembered and given meaning for new times. In this sense, for James, as for later modernists, his treatment of the past is always also about what is to come.

Even at the end of his life, after suffering two strokes in December 1915, James, a ruin himself now, bedridden and at times barely conscious, seems to have been preoccupied with these questions. On 12 December, he dictated a letter that seems to be from Napoleon Bonaparte to the Emperor's brother and sister. It might have been part of a new novel, but its significance remains unclear. ${ }^{65}$ The letter begins:

Dear and most esteemed brother and sister,

I call your attention to the precious enclosed transcripts of plans and designs for the decorations of certain apartments of the palaces, here, of the Louvre and the Tuileries, which you will find addressed in detail to artists and workmen who are to take them in hand. I commit them to your earnest care till the questions relating to this important work are fully settled. When that is the case I shall require of you further zeal and further taste. For the present the course is definitely marked out, and I beg you to let me know from stage to stage definitely how the scheme promises, and what results it may be held to inspire. It is, you will see, of a great scope, a majesty unsurpassed by any work of the kind yet undertaken in France. Please understand I regard these plans as fully developed and as having had my last consideration and look forward to no patchings nor perversions, and with no question of modifications either economic or aesthetic. This will be the case with all further projects of your affectionate

. Napoléone $e^{66}$

We can only speculate about what this fragment meant or how it was supposed to fit in to a projected larger work. Peter Brooks sees it as evidence of the deep influence France had on his life and work, ${ }^{67}$ but what is of interest to this article is that, weakened and almost at the point of death, James's thoughts turned again to restoration-and 
once again it is the Palais des Tuileries that is calling for improvement. As in all James's work, where the Tuileries are alluded to, revolution is never far from the surface. The modernist conjuncture, as Perry Anderson reminded us almost thirty years ago, occurred in "imaginative proximity [with] social revolution." ${ }^{68}$ If the author who prompts the memory is at first a surprise, it is nonetheless a reminder that modernist studies would be wise not to forget. To repeat James's words of 1872: "Beneath all this neatness \& coquetry" we can still "smell the Commune suppressed, but seething."

\section{Notes}

1. James, The Ambassadors, 76.

2. Nora, General Introduction: Between Memory and History, 12.

3. See Coghlan, Aftertastes of Ruin: Uncanny Sites of Memory in Henry James's Paris.

4. Proust, Du côté de chez Swann, 1: 57.

5. Benjamin, "On the Concept of History," 390.

6. James, Transatlantic Sketches, 286.

7. See for example, Schivelbusch, The Culture of Defeat, 112.

8. Ohi, "Belatedness and Style."

9. Ibid., 128.

10. Ibid., 140.

11. James, A Small Boy and Others, 57-8.

12. Ibid.

13. See Brooks, Henry James Goes to Paris, 8.

14. See for example, James, Notes of a Son and Brother, 408-409.

15. James, Complete Letters 1855-1872, 1: 176, 177.

16. James, Complete Letters 1855-1872, 2: 373-4.

17. Ibid., 373.

18. Ibid., 400-401.

19. See Brooks, Henry James Goes to Paris, 7-52.

20. James, The Complete Letters 1872-1876, 1: 34.

21. Coghlan, "Aftertastes of Ruin: Uncanny Sites of Memory in Henry James's Paris," 240; see also Wilson, Paris and the Commune, 1871-78, 186.

22. James, Transatlantic Sketches, 99.

23. James, The Complete Letters 1872-1876, 1: 127, 131.

24. Ibid., 149.

25. Ibid., 150.

26. Ibid., 114.

27. Ibid.

28. Ibid., 130.

29. Ibid., 150.

30. Ibid., 157.

31. Supporters of the Bourbon family, descendants of Louis XVI.

32. Poole, "The Revised Version for the New York Edition," 371.

33. On James and revision, see Horne, Henry James and Revision, and McWhirter, Henry James's New York Edition: The Construction of Authorship.

34. James, The American, 176.

35. Benjamin, The Arcades Project, 9.

36. In "The Politics of Innocence," John Carlos Rowe suggests that the novel is read as a political allegory, in which case the Bellegardes represent a return to a dark, feudal past; but if, as Rowe argues, Newman is culpably ignorant of French politics, then it is his inability to comprehend the continuing power of that past in the present until it is too late that loses him his wife to be. 


\section{MODER N I M / modernity}

37. Fonkenell, Le Palais des Tuileries, 199.

38. Lissagaray, Histoire de la Commune de Paris, 338.

39. Fonkenell, Le Palais des Tuileries, 199.

40. Wilson, Paris and the Commune, 1871-78, 179.

41. Babelon, "Le Louvre," 194.

42. Maxime Du Camp, cited in Fonkenell, Le Palais des Tuileries, 199.

43. Fussell, The French Side of Henry James, 27-31.

44. Fonkenell, Le Palais des Tuileries, 201.

45. Ibid., 201-212.

46. Wilson, Paris and the Commune, 1871-78, 189.

47. Fonkenell, Le Palais des Tuileries, 214.

48. Ibid., 212

49. Wilson, Paris and the Commune, 1871-78, 185.

50. James, The Complete Letters 1872-1876, 1: 143.

51. James, Transatlantic Sketches, 284-5.

52. Ibid., 286.

53. James, Portrait of a Lady, 213.

54. James, Princess Casamassima, 393.

55. It is also alluded to in a short story "Collaboration" (1893), but this is more about the legacy of the Franco-Prussian war than the Commune.

56. Either 1830 or 1848; the novel is not explicit. James, Princess Casamassima, 167.

57. Coghlan writes that "Hyacinth's trip to the missing barricades....anticipates Strether's visit to the Palace that is not there, even as it draws our attention to the irremediable voids in the landscape and the layers that lie beneath them" ("Aftertastes of Ruin: Uncanny Sites of Memory in Henry James's Paris," 245).

58. James, The Ambassadors, 76.

59. Ibid., 76.

60. Benjamin, "Literaturgeschichte und Literaturwissenschaft," 290 (my translation).

61. This is Ohi's conclusion: "To live might...be less to be on the train than to realize that one should regret having missed it, and to find oneself, perhaps, no longer at a loss to name what one has lost"("Belatedness and Style," 131).

62. James, The Ambassadors, 433.

63. Ibid.

64. James, Princess Casamassima, 393.

65. See Brooks, Henry James Goes to Paris, 210; Novick, The Mature Master, 519; Horne, Henry James and Revision, 322-3.

66. James, Letters 1895-1916, 4: 811.

67. Brooks, Henry James Goes to Paris, 210.

68. Anderson, "Modernity and Revolution," 104.

\section{Works Cited}

Anderson, Perry. "Modernity and Revolution." New Left Review 144 (April 1984): 96-113.

Babelon, Jean-Pierre. "Le Louvre." Les lieux de mémoire. Vol. 2. Paris: Gallimard, 1992. 169-216.

Benjamin, Walter. Das Passagen-Werk. Vol. I. Frankfurt am Main: Suhrkamp Verlag, 1982.

. "Literaturgeschichte und Literaturwissenschaft." Gesammelte Schriften. Ed. R. Tiedemann

and H. Schweppenhauser. Vol. 3. Frankfurt am Main: Suhrkamp Verlag, 1972. 283-290.

. "On the Concept of History." Selected Writings 1938-40. Ed. Howard Eiland and

Michael W. Jennings. Trans. Edmund Jephcott et al. Vol. 4. Cambridge, MA: The Belknap Press of Harvard University Press, 2003. 389-400.

. The Arcades Project. Trans. Howard Eiland and Kevin McLaughlin. Cambridge,MA: The

Belknap Press of Harvard University Press, 1999. 
Brooks, Peter. Henry James Goes to Paris. Princeton: Princeton University Press, 2007.

Coghlan, J. Michelle. “Aftertastes of Ruin: Uncanny Sites of Memory in Henry James's Paris." Henry James Review 33 (2012): 239-246.

Fonkenell, Guillaume. Le Palais des Tuileries. Arles: Editions Honoré Clair, 2010.

Fussell, Edwin Sill. The French Side of Henry James. New York: Columbia University Press, 1990.

Horne, Philip. Henry James and Revision. Oxford: Clarendon Press, 1990.

James, Henry. A Small Boy and Others. London: Macmillan, 1913.

- Henry James Letters 1895-1916. Ed. Leon Edel. Vol. 4. Cambridge, MA: The Belknap Press of Harvard University Press, 1984.

- Notes of a Son and Brother. Scribner, 1914.

- The Ambassadors. Ed. Derek Brewer. London: Penguin, 2008.

- The American. Ed. Adrian Poole. Oxford: Oxford University Press, 2009.

. The Complete Letters of Henry James 1855-1872. Ed. P. A Walker and G. W Zacharias. Vol.

1. Lincoln: University of Nebraska Press, 2006.

. The Complete Letters of Henry James 1872-1876. Vol. 1. Lincoln: University of Nebraska Press, 2008

- The Complete Letters of Henry James, 1855-1872. Ed. P. A. Walker and G. W. Zacharias. Vol.

2. Lincoln: University of Nebraska Press, 2006.

- The Portrait of a Lady. Harmondsworth: Penguin, 1966.

. The Princess Casamassima. Ed. P. Crick. London: Penguin Books, 1987.

Transatlantic Sketches. Boston: J. R. Osgood, 1875.

Lissagaray, Prosper. Histoire de la Commune de Paris. Brussels: Librarie Contemporaine de Henri Kistemaeckers, 1876.

McWhirter, D. B. Henry James's New York Edition: The Construction of Authorship. Palo Alto, CA: Stanford University Press, 1995.

Nora, Pierre. "General Introduction: Between Memory and History." Realms of Memory. Ed. Lawrence D. Kritzman. Trans. Arthur Goldhammer. Vol. 1. New York: Columbia University Press, 1996. 1-20. Novick, Sheldon M. The Mature Master: Henry James. New York: Random House, 2007.

Ohi, Kevin. "Belatedness and Style." Palgrave Advances in Henry James Studies. Ed. Peter Rawlings. Basingstoke: Palgrave Macmillan, 2007. 126-146.

Poole, Adrian. "The Revised Version for the New York Edition.” The American. Ed. Adrian Poole. Oxford: Oxford University Press, 2009. 367-384.

Proust, Marcel. Du côté de chez Swann, A la recherche du temps perdu, Vol. I. Paris: Le Livre de Poche/ Gallimard, 1954.

Rowe, John Carlos. "The Politics of Innocence in Henry James The American.” New Essays on The American. Ed. Martha Banta. Cambridge: University of Cambridge Press, 1987. 69-98.

Schivelbusch, Wolfgang. The Culture of Defeat: On National Trauma, Mourning and Recovery. Trans. Jefferson Chase. London: Granta, 2003.

Wilson, Colette E. Paris and the Commune, 1871-78: The Politics of Forgetting. Manchester: Manchester University Press, 2007. 
